\title{
Connexin26 hemichannels with a mutation that causes KID syndrome in humans lack sensitivity to $\mathrm{CO}_{2}$
}

\author{
Louise Meigh ${ }^{1}$, Naveed Hussain ${ }^{2}$, Daniel K Mulkey ${ }^{3}$, Nicholas Dale ${ }^{1 *}$
}

${ }^{1}$ School of Life Sciences, University of Warwick, Coventry, United Kingdom; ${ }^{2}$ Division of Neonatal Pediatrics, Connecticut Children's Medical Center NICU, University of Connecticut Health Center, Farmington, United States; ${ }^{3}$ Department of Physiology and Neurobiology, University of Connecticut, Storrs, United States

\begin{abstract}
Mutations in connexin26 (Cx26) underlie a range of serious human pathologies. Previously we have shown that $\mathrm{C} \times 26$ hemichannels are directly opened by $\mathrm{CO}_{2}$ (Meigh et al., 2013). However the effects of human disease-causing mutations on the $\mathrm{CO}_{2}$ sensitivity of $\mathrm{C} \times 26$ are entirely unknown. Here, we report the first connection between the $\mathrm{CO}_{2}$ sensitivity of $\mathrm{Cx} 26$ and human pathology, by demonstrating that $\mathrm{C} \times 26$ hemichannels with the mutation $\mathrm{A} 88 \mathrm{~V}$, linked to Keratitis-IchthyosisDeafness syndrome, are both $\mathrm{CO}_{2}$ insensitive and associated with disordered breathing in humans. DOI: 10.7554/eLife.04249.001
\end{abstract}

*For correspondence: n.e.dale@ warwick.ac.uk

Competing interests: The authors declare that no competing interests exist.

Funding: See page 6

Received: 05 August 2014 Accepted: 17 November 2014 Published: 25 November 2014

Reviewing editor: Michael A Marletta, The Scripps Research Institute, United States

(c) Copyright Meigh et al. This article is distributed under the terms of the Creative Commons Attribution License, which permits unrestricted use and redistribution provided that the original author and source are credited.
Connexin26 (Cx26) is one of 21 connexin genes found in humans (Cruciani and Mikalsen, 2006). The canonical function of connexins is to form gap junctions in which two hexameric connexons, or hemichannels, in closely apposed membranes dock together to form an intercellular channel. However connexins can also function as hemichannels, thereby providing large conductance channels, which allow passage of small molecules such as ATP into the extracellular space (Stout et al., 2004; Wang et al., 2013). We have recently shown that $\mathrm{C} \times 26$ hemichannels are directly sensitive to $\mathrm{CO}_{2}$ (Huckstepp et al., 2010a; Meigh et al., 2013). When $\mathrm{CO}_{2}$ binds to $\mathrm{C} \times 26$, it carbamylates $\mathrm{K} 125$, forms a salt bridge to R104 and opens the hemichannel (Meigh et al., 2013). Cx26 hemichannels are thus a source of $\mathrm{CO}_{2}$-gated ATP release (Huckstepp et al., 2010a).

Mutations of $\mathrm{C} \times 26$ are the commonest cause of non-syndromic hearing loss (Cohn and Kelley, 1999; Kelley et al., 2000; Xu and Nicholson, 2013). Some of these mutations cause loss of functional protein, while other mutations result in gap junctions and hemichannels with altered properties. However the effect of these mutations on the $\mathrm{CO}_{2}$ sensitivity of $\mathrm{C} \times 26$ has never been examined. Some missense mutations of $\mathrm{C} \times 26$ cause serious pathologies in humans, such as the very rare ectodermal disorder, Keratitis-Ichthyosis-Deafness (KID) syndrome. KID syndrome involves a combination of deafness, visual impairment, and dermatological abnormalities (Caceres-Rios et al., 1996). About 100 cases have been reported in the literature, and of these around $70 \%$ are caused by de novo mutations in $\mathrm{C} \times 26$, with the remainder being inherited in an autosomal dominant manner or via germ line mosaicism (Sbidian et al., 2010). To date there are nine missense mutations that can cause KID syndrome (Xu and Nicholson, 2013). The severity of the symptoms of KID syndrome depends on the particular mutation in Cx26 (Janecke et al., 2005; Jonard et al., 2008).

The mutation, $\mathrm{C} \times 26^{\mathrm{A} 88 \mathrm{~V}}$, is linked to a very severe form of KID syndrome, which is fatal in infancy (Haruna et al., 2010; Koppelhus et al., 2010). In one of the original reports linking Cx26 $6^{\mathrm{ABV}}$ to KID syndrome, the patient required mechanical ventilation (Koppelhus et al., 2010), suggesting a possible effect of the mutation on the neural control of breathing. In KID syndrome caused by a different missense mutation (G45E), which is fatal within the first year of life, there are also reports of breathing problems. One patient required mechanical ventilation immediately after birth (Janecke et al., 2005) 
and a second died from breathing failure (Sbidian et al., 2010). Nevertheless, without detailed recordings of cardiorespiratory activity, it is not possible to know whether these patients experienced inadequate central respiratory drive. For other mutations linked to KID syndrome there are no reports of abnormal breathing in the literature.

The reason why the $\mathrm{A} 88 \mathrm{~V}$ and $\mathrm{G} 45 \mathrm{E}$ mutations should cause such pervasive and severe pathology remains unclear as subunits of $C \times 26^{\mathrm{AB8V}}$ and $\mathrm{C} \times 26^{\mathrm{G} 45 \mathrm{E}}$ form both functional gap junctions and hemichannels (Gerido et al., 2007; Mhaske et al., 2013). Expression of Cx26 ${ }^{A 88 V}$ in HeLa cells gives rise to enhanced hemichannel-mediated currents (compared to wild type $\mathrm{C} \times 26, \mathrm{C} \times 26^{\mathrm{WT}}$ ) at positive transmembrane potentials and in the absence of extracellular $\mathrm{Ca}^{2+}$, leading to the suggestion that this mutation represents a gain of function (Mhaske et al., 2013). The G45E mutation, also causes enhanced hemichannel activity in the absence of extracellular $\mathrm{Ca}^{2+}$, and increased permeability to $\mathrm{Ca}^{2+}$ (Gerido et al., 2007; Sanchez et al., 2010). A gain of function has therefore been suggested as underlying the actions of this mutation too. Although the absence of extracellular $\mathrm{Ca}^{2+}$ opens connexin hemichannels, this condition is unlikely to occur in physiological systems. Thus the consequences of the A88V and G45E mutations on physiologically relevant gating of Cx26 remain unclear.

We identified a patient with KID syndrome caused by a heterozygous Cx26 A88V mutation. This patient failed to breathe spontaneously at birth and initially required mechanical ventilation. Later when he started to breathe spontaneously, he continued to demonstrate periods of apnea and bradycardia. A pneumogram performed at a post-menstrual age of 40 weeks showed abnormal persistence of central apnea lasting $\geq 20 \mathrm{~s}$ and accompanied by periods of bradycardia and prolonged oxygen desaturation (Figure 1). This respiratory pattern is abnormal for the age of the infant and is suggestive of blunted chemosensory control of breathing. Given the previously described role of Cx26 in mediating the $\mathrm{CO}_{2}$-dependent drive to breathe (Huckstepp et al., 2010b; Wenker et al., 2012), we considered whether the mutation $\mathrm{A} 88 \mathrm{~V}$ might alter the $\mathrm{CO}_{2}$-sensitivity of $\mathrm{C} \times 26$.

We introduced the A88V mutation into $\mathrm{C} \times 26$ and then tested the $\mathrm{CO}_{2}$ sensitivity of $\mathrm{C} \times 26^{\mathrm{A} 88 \mathrm{~V}}$ hemichannels expressed in HeLa cells via an established and sensitive dye-loading protocol (Huckstepp et al., 2010a; Meigh et al., 2013). Under conditions of normal extracellular $\mathrm{Ca}^{2+}{ }^{+}$HeLa cells expressing wild type $\mathrm{C} \times 26$ hemichannels readily load with carboxyfluorescein when exposed to a moderately hypercapnic saline ( $\mathrm{PCO}_{2} 55 \mathrm{mmHg}$ ) (Huckstepp et al., 2010a; Meigh et alı, 2013). However HeLa cells expressing $\mathrm{C} \times 26^{\mathrm{A} 88 \mathrm{~V}}$ showed no such $\mathrm{CO}_{2}$-dependent dye loading even when exposed to higher

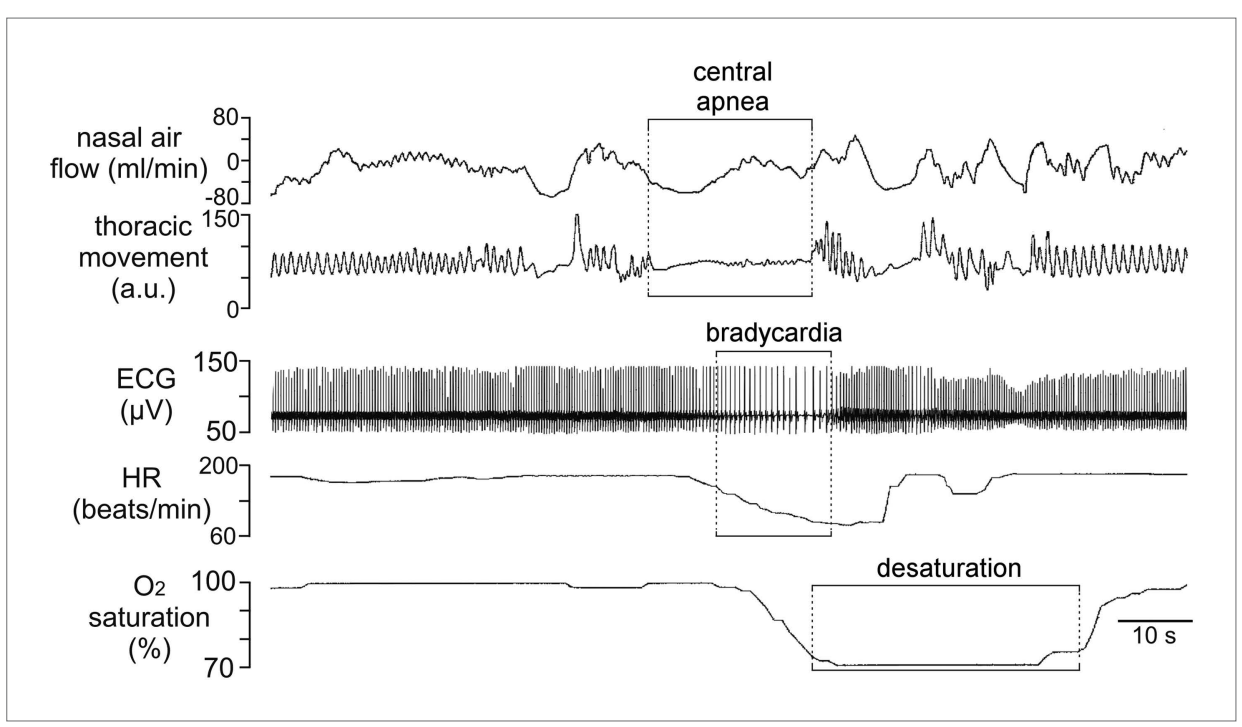

Figure 1. Incidence of central sleep apnea in a patient with $C \times 26^{A 88 V}$. Recording of cardiorespiratory activity during sleep from an infant at a post-menstrual age of 40 weeks diagnosed with KID syndrome. Traces of nasal air flow, thoracic movement, electrocardiogram (ECG), heart rate (HR) and arterial $\mathrm{O}_{2}$ saturation show that this patient exhibited a prolonged period during which no effort was made to breathe and this was followed by pronounced bradycardia and arterial $\mathrm{O}_{2}$ desaturation, all of which are characteristic of central sleep apnea. Unfortunately, at 2 months of age this patient died from overwhelming sepsis.

DOI: 10.7554/eLife.04249.002 
levels of $\mathrm{PCO}_{2}\left(70 \mathrm{mmHg}\right.$, Figure 2). The failure to exhibit $\mathrm{CO}_{2}$-dependent dye loading was not due to a lack of functional hemichannels as the positive control of removing extracellular $\mathrm{Ca}^{2+}$, which opens all connexin hemichannels, caused robust dye loading (Figure 2). HeLa cells transfected with an empty vector do not show any dye loading in response to a $\mathrm{CO}_{2}$ stimulus or removal of extracellular $\mathrm{Ca}^{2+}$ (Figure 2-figure supplement 1). Surprisingly therefore, the conservative mutation A88V caused $\mathrm{C} \times 26$ hemichannels to lose their sensitivity to $\mathrm{CO}_{2}$. As this mutation is far from the residues involved in $\mathrm{CO}_{2}$ binding (K125 and R104), the mechanism for the loss of $\mathrm{CO}_{2}$ sensitivity is unclear.

As the missense mutations which underlie KID syndrome act in a dominant manner (Jonard et alo, 2008; Xu and Nicholson, 2013), we tested whether the expression of Cx26 ${ }^{\mathrm{A} 88 \mathrm{~V}}$ subunits might have a dominant negative action on the $\mathrm{CO}_{2}$ sensitivity of $\mathrm{C} \times 26^{\mathrm{WT}}$. We transfected HeLa cells that stably expressed $\mathrm{C} \times 26^{\mathrm{WT}}$ with the $\mathrm{C} \times 26^{\mathrm{A88V}}$ subunit and documented their sensitivity to $\mathrm{CO}_{2}$ following transfection. 4 days after transfection with $\mathrm{C} \times 26^{\mathrm{AB8V}}$, the HeLa cells still exhibited sensitivity to $\mathrm{CO}_{2}$ (Figure $3 \mathrm{~A}$ ), but this was reduced compared to the $\mathrm{C} \times 26^{\mathrm{WT}} \mathrm{HeLa}$ cells that had not been transfected with $\mathrm{C} \times 26^{\mathrm{A}}{ }^{\text {aV }}$ (Figure 3B). 5 and 6 days after transfection, the HeLa cells showed no sensitivity to $\mathrm{CO}_{2}$ (Figure 3A). Nevertheless functional hemichannels were still present as the removal of extracellular $\mathrm{Ca}^{2+}$ caused dye loading (Figure 3A). The loss of $\mathrm{CO}_{2}$ sensitivity was not simply a consequence of days in
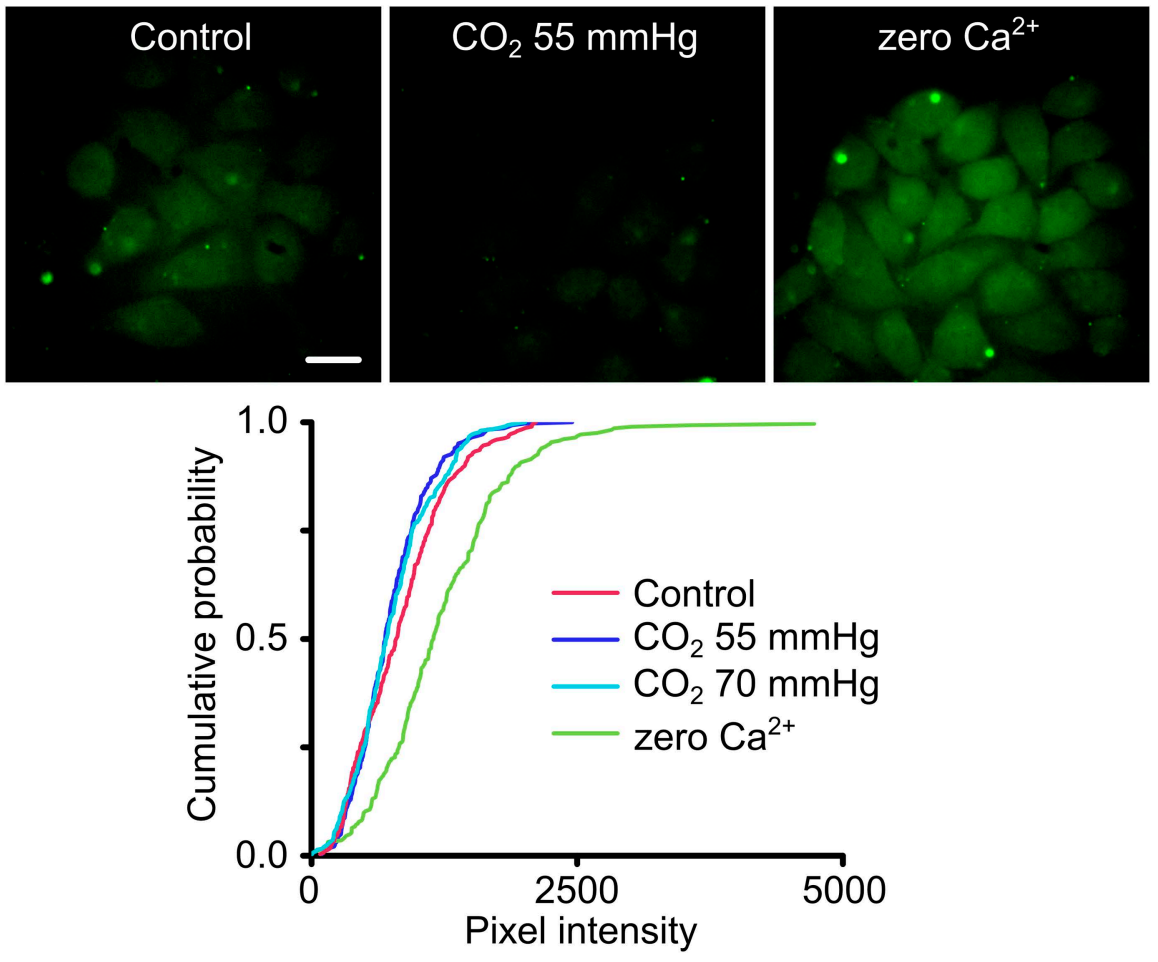

Figure 2. $\mathrm{C} \times 26^{\mathrm{AB8V}}$ hemichannels are no longer sensitive to $\mathrm{CO}_{2}$. (Top) Images of HeLa cells expressing $\mathrm{C} \times 26^{\mathrm{A} 88 \mathrm{~V}}$ under control, hypercapnic and zero $\mathrm{Ca}^{2+}$ conditions. The cells were exposed to $200 \mu \mathrm{M}$ carboxyfluorescein (CBF) for 5 min under each condition before being washed. Some low background loading of CBF is seen under control conditions. In presence of $\mathrm{CO}_{2}$ no loading is seen. The positive control of removal of extracellular $\mathrm{Ca}^{2+}$ causes robust dye loading demonstrating the presence of functional hemichannels. (Bottom) Cumulative probability distributions of pixel intensity of HeLa cells expressing $\mathrm{C}_{2} 26^{\mathrm{A88V}}$ under control, hypercapnia (two levels of $\mathrm{PCO}_{2}$ ) and zero $\mathrm{Ca}^{2+}$ Only the removal of extracellular $\mathrm{Ca}^{2+}$ causes dye loading as shown by the rightward shift of the curve to higher pixel intensities ( $p=0.004$, Mann Whitney $U$ test compared to control). These distributions show all of the measurements made (minimum 40 cells each from five independent repetitions).

DOI: 10.7554/eLife.04249.004

The following figure supplement is available for figure 2:

Figure supplement 1. HeLa cells transfected with the empty pCAG-GS mCherry vector show no sensitivity to $\mathrm{CO}_{2}$ and do not dye load when exposed to zero $\mathrm{Ca}^{2+}$ aCSF.

DOI: 10.7554/eLife.04249.003 


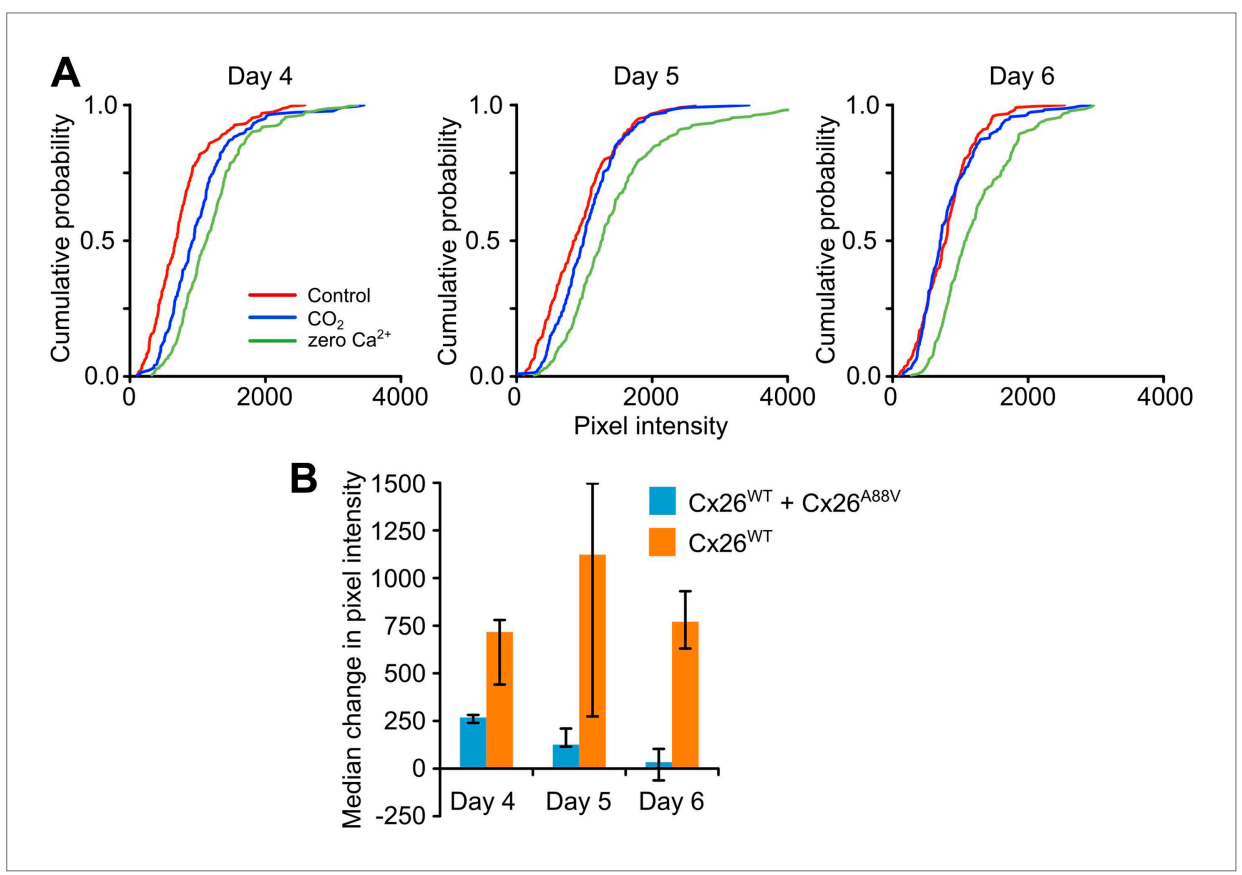

Figure 3. $\mathrm{C} \times 26^{\mathrm{A} 88 \mathrm{~V}}$ hemichannels act in a dominant negative manner to remove $\mathrm{CO}_{2}$ sensitivity from $\mathrm{C} \times 26^{\mathrm{WT}}$. (A) Cumulative probability distributions for $\mathrm{CO}_{2}$-dependent dye loading in $\mathrm{HeLa}$ cells that stably express $\mathrm{C} \times 26$ WT, which have been transfected with $\mathrm{C} \times 26^{\mathrm{A} 88 \mathrm{~V}}$. 4 days after transfection with $\mathrm{C} \times 26^{\mathrm{A} 88 \mathrm{~V}}$ the cells still exhibit significant sensitivity to $55 \mathrm{mmHg} \mathrm{PCO}_{2}$ stimulus ( $\mathrm{p}=0.048 \mathrm{CO}_{2}$ compared to control, Mann Whitney $U$ test). 5 and 6 days after transfection the $\mathrm{CO}_{2}$ sensitivity of the HeLa cells was abolished. On all 3 days, the positive control of zero $\mathrm{Ca}^{2+}$ caused dye loading, demonstrating the presence of functional hemichannels. The graphs show all of the measurements made from 5 independent repetitions of the experiment. (B) Comparison of the sensitivity to $\mathrm{CO}_{2}$ of $\mathrm{HeLa}$ cells stably expressing Cx26 ${ }^{\text {WT }}$ which have been transfected with $\mathrm{C} \times 26^{\mathrm{AB8V}}\left(\mathrm{C} \times 26^{\mathrm{WT}}+\mathrm{C} \times 26^{\mathrm{AB8V}}, \mathrm{n}=5\right)$ with those that have not $\left(\mathrm{C} \times 26^{W T}, \mathrm{n}=7\right)$. In the absence of transfection, the $\mathrm{C} \times 26^{W T}$-expresssing HeLa cells retain sensitivity to $\mathrm{CO}_{2}$ on all 3 days. By contrast $\mathrm{Cx} 26^{\mathrm{A} 88 \mathrm{~V}}$ causes significantly depressed $\mathrm{CO}_{2}$ sensitivity 4 days after transfection $(p=0.001)$, and loss of sensitivity on days $5(p=0.024)$ and $6(p=0.001)$. Comparisons of $C \times 26^{\text {WT }}$ with $C \times 26^{\text {WT }}+C \times 26^{\text {A88V }}$ via Mann Whitney U test, and False Discovery Rate procedure for multiple comparisons (Curran-Everett, 2000). Error bars upper and lower quartiles.

DOI: 10.7554/eLife.04249.005

culture, as $\mathrm{C} \times 26^{\text {WT }} \mathrm{HeLa}$ cells that had not been transfected with $\mathrm{C} \times 26^{\mathrm{A} 88 \mathrm{~V}}$ retained their sensitivity to $\mathrm{CO}_{2}$ over the whole period examined (Figure $3 \mathrm{~B}$ ). We therefore conclude that $\mathrm{Cx} 26^{\mathrm{A} 88 \mathrm{~V}}$ subunits are able to act in a dominant negative manner to cause loss of $\mathrm{CO}_{2}$ sensitivity from wild type $\mathrm{C} \times 26$ hemichannels.

This is the first instance in which a mutation linked to serious human pathologies has been demonstrated to abolish the $\mathrm{CO}_{2}$ sensitivity of $\mathrm{Cx} 26$. This in turn suggests that $\mathrm{Cx} 26$-mediated $\mathrm{CO}_{2}$ sensing may be important for human physiology in the range of contexts that are associated with the diverse pathologies linked to this mutation. In the closely related $\beta$ connexin, connexin30 (Cx30), the mutation A88V connected to Clouston's Syndrome (Bosen et al., 2014), may result in constitutively open Cx30 hemichannels (Essenfelder et al., 2004). However $\mathrm{Cx30}$ is also opened by $\mathrm{CO}_{2}$ (Huckstepp et al., 2010a) and the effect of this mutation on the $\mathrm{CO}_{2}$ sensitivity of $\mathrm{Cx} 30$ has not yet been investigated. There are no reports in the literature of disordered breathing in patients with Clouston's syndrome.

Previous studies suggesting that the A88V mutation gave a gain of function in $\mathrm{Cx} 26$, examined hemichannel function in the absence of extracellular $\mathrm{Ca}^{2+}$ (Mhaske et alo, 2013). As the $\mathrm{CO}_{2}$ sensitivity of the mutated hemichannel was not specifically examined in this previous study, it is likely that both sets of findings are correct-an enhancement of macroscopic hemichannel currents (Mhaske et al., 2013), and a loss of $\mathrm{CO}_{2}$ sensitivity. However under physiological conditions of normal extracellular $\mathrm{Ca}^{2+}$ and in the presence of physiological $\mathrm{CO}_{2} / \mathrm{HCO}_{3}^{-}$buffering, we suggest that $\mathrm{A} 88 \mathrm{~V}$ should be considered as a loss-of-function mutation that effectively removes the capacity for $\mathrm{CO}_{2}$-evoked ATP release via $\mathrm{Cx} 26$ hemichannels. 
Our report is the first to document altered central respiratory drive in a KID syndrome patient. In rodents, $\mathrm{CO}_{2}$-sensitivity of $\mathrm{Cx} 26$ contributes to the chemosensory control of breathing (Huckstepp et al., 2010b; Wenker et al., 2012). Although we do not know if the loss of $\mathrm{CO}_{2}$ sensitivity in $\mathrm{Cx} 26$ contributed to the aberrant respiratory drive exhibited by this patient, these results are consistent with this possibility, and represent the first evidence to suggest that Cx26 hemichannels are a requisite component of the drive to breathe in humans. Overall the ability of physiological levels of $\mathrm{PCO}_{2}$ to permit ATP release via $\mathrm{C} \times 26$ hemichannels may be important in the epidermis, cochlea and brain. Investigation of whether the absence of this mechanism of ATP release in patients with Cx26 ${ }^{\text {A88V }}$ contributes to the serious pathological abnormalities that they suffer would seem to be warranted.

\section{Materials and methods}

\section{Case study}

The Institutional Review Board of the Connecticut Children's Medical Center considered this under the category of a case report and thus exempt from formal review.

\section{Mutant connexin production}

Puc19 Cx26 ${ }^{\mathrm{A} 88 \mathrm{~V}}$ was produced from wild type Cx26 via the Quikchange protocol using the following primers: forward 5' TGT CCA CGC CGG TCC TCC TGG TAG C 3' reverse 5' GCT ACC AGG AGG ACC GGC GTG GAC A 3'. Cx26 ${ }^{A 88 V}$ was subcloned into a pCAG-GS mCherry vector for mammalian cell transfection. Successful mutation of $\mathrm{C} \times 26$ was confirmed by sequencing which also verified that apart from the desired mutation the sequence was identical to the wild type.

\section{HeLa cell culture}

HeLa cells were cultured by standard methods in DMEM, 10\% FCS with addition of $3 \mathrm{mM} \mathrm{CaCl}_{2}$. For experimentation, cells were plated onto coverslips at a density of $5 \times 10^{4}$ cells per well. Transient transfections were performed using the genejuice protocol.

\section{Solutions used}

\section{Control aCSF}

$124 \mathrm{mM} \mathrm{NaCl}, 26 \mathrm{mM} \mathrm{NaHCO}_{3}, 1.25 \mathrm{mM} \mathrm{NaH}_{2} \mathrm{PO}_{4}, 3 \mathrm{mM} \mathrm{KCl}, 10 \mathrm{mM}$ D-glucose, $1 \mathrm{mM} \mathrm{MgSO}$, $1 \mathrm{mM}$ $\mathrm{CaCl}_{2}$.

\section{Zero $\mathrm{Ca}^{2+} \mathrm{aCSF}$}

$124 \mathrm{mM} \mathrm{NaCl}, 26 \mathrm{mM} \mathrm{NaHCO}_{3}, 1.25 \mathrm{mM} \mathrm{NaH}_{2} \mathrm{PO}_{4}, 3 \mathrm{mM} \mathrm{KCl}, 10 \mathrm{mM}$ D-glucose, $1 \mathrm{mM} \mathrm{MgSO}$, $1 \mathrm{mM}$ $\mathrm{MgCl}_{2}, 1 \mathrm{mM}$ EGTA.

Hypercapnic $(55 \mathrm{mmHg} \mathrm{CO}$ ) aCSF

$100 \mathrm{mM} \mathrm{NaCl}, 50 \mathrm{mM} \mathrm{NaHCO}_{3}, 1.25 \mathrm{mM} \mathrm{NaH}_{2} \mathrm{PO}_{4}, 3 \mathrm{mM} \mathrm{KCl}, 10 \mathrm{mM}$-glucose, $1 \mathrm{mM} \mathrm{MgSO}$, $1 \mathrm{mM}$ $\mathrm{CaCl}_{2}$.

\section{Hypercapnic $(70 \mathrm{mmHg} \mathrm{CO} 2)$ aCSF}

$70 \mathrm{mM} \mathrm{NaCl}, 80 \mathrm{mM} \mathrm{NaHCO}_{3}, 1.25 \mathrm{mM} \mathrm{NaH}_{2} \mathrm{PO}_{4}, 3 \mathrm{mM} \mathrm{KCl}, 10 \mathrm{mM}$ D-glucose, $1 \mathrm{mM} \mathrm{MgSO}$, 1 mM $\mathrm{CaCl}_{2}$.

Hypercapnic aCSF was saturated with sufficient $\mathrm{CO}_{2}$ (the remaining balance being $\mathrm{O}_{2}$ ) to adjust the final $\mathrm{pH}(\mathrm{pH} 7.5)$ to that of the control aCSF removing any potential effects of changes in extracellular $\mathrm{pH}$.

All other solutions were saturated with $95 \% \mathrm{O}_{2} / 5 \% \mathrm{CO}_{2}$.

\section{Dye loading protocols}

Coverslips plated with HeLa cells transiently transfected with $\mathrm{C} x 26^{\mathrm{A} 88 \mathrm{~V}}$ were exposed to Hypercapnic aCSF $(55 \mathrm{mmHg}$ or $70 \mathrm{mmHg}$ ) containing $200 \mu \mathrm{M}$ CBF for $10 \mathrm{~min}$. This was followed by control aCSF with $200 \mu \mathrm{M} \mathrm{CBF}$ for $5 \mathrm{~min}$ and a $30 \mathrm{~min}$ wash with control aCSF to ensure that all dye is removed from the outside of the cells.

A control comparison was used to establish any baseline loading occurring in the absence of a stimulus. HeLa cells expressing Cx26 ${ }^{\mathrm{A} 88 \mathrm{~V}}$ were exposed to $200 \mu \mathrm{M}$ CBF in control aCSF for 15 min, followed by 30 min of washing. 
A zero $\mathrm{Ca}^{2+}$ positive control was also performed to ensure functional connexin hemichannels were being expressed. Cx26 ${ }^{\mathrm{A} 88 \mathrm{~V}}$ expressing HeLa cells were exposed to $200 \mu \mathrm{M} \mathrm{CBF}$ in zero $\mathrm{Ca}^{2+}$ aCSF for $10 \mathrm{~min}$. This was followed by control aCSF with $200 \mu \mathrm{M}$ CBF for 5 min and $30 \mathrm{~min}$ of washing with aCSF.

\section{Imaging and analysis}

For each condition cells were imaged by epifluorescence (Scientifica Slice Scope, Cairn Research OptoLED illumination, 60x water Olympus immersion objective, NA 1.0, Hamamatsu ImageEM EMCCD camera, Metafluor software). Using ImageJ, the extent of dye loading was measured by drawing a region of interest ( $\mathrm{ROI}$ ) around individual cells and calculating the mean pixel intensity for the ROI. The mean pixel intensity of the background fluorescence was also measured in a representative ROI, and this value was subtracted from the measures obtained from the cells. All of the images displayed in the figures reflect this procedure in that the mean intensity of the pixels in a representative background $\mathrm{ROI}$ has been subtracted from every pixel of the image. The analysis of the $\mathrm{CO}_{2}$ sensitivity of $\mathrm{C} \times 26^{\mathrm{A} 88 \mathrm{~V}}$ was performed as five independent repetitions in which at least 40 cells were measured in each condition, and the mean pixel intensities plotted as cumulative probability distributions.

\section{Additional information}

Funding

\begin{tabular}{lll} 
Funder & Grant reference number & Author \\
\hline Medical Research Council & G1001259 & Nicholas Dale
\end{tabular}

The funder had no role in study design, data collection and interpretation, or the decision to submit the work for publication.

Author contributions

$\mathrm{LM}, \mathrm{NH}$, Conception and design, Acquisition of data, Analysis and interpretation of data, Drafting or revising the article; DKM, ND, Conception and design, Analysis and interpretation of data, Drafting or revising the article

Ethics

Human subjects: The Institutional Review Board of the Connecticut Children's Medical Center considered this under the category of a case report and thus exempt from formal review.

\section{References}

Bosen F, Schutz M, Beinhauer A, Strenzke N, Franz T, Willecke K. 2014. The Clouston syndrome mutation connexin30 A88V leads to hyperproliferation of sebaceous glands and hearing impairments in mice. FEBS Letters 588:1795-1801. doi: 10.1016/j.febslet.2014.03.040.

Caceres-Rios H, Tamayo-Sanchez L, Duran-Mckinster C, de la Luz Orozco M, Ruiz-Maldonado R. 1996. Keratitis, ichthyosis, and deafness (KID syndrome): review of the literature and proposal of a new terminology. Pediatric Dermatology 13:105-113. doi: 10.1111/j.1525-1470.1996.tb01414.x.

Cohn ES, Kelley PM. 1999. Clinical phenotype and mutations in connexin 26 (DFNB1/GJB2), the most common cause of childhood hearing loss. American Journal of Medical Genetics 89:130-136. doi: 10.1002/ (SICI)1096-8628(19990924)89:3<130::AID-AJMG3>3.0.CO;2-M.

Cruciani V, Mikalsen SO. 2006. The vertebrate connexin family. Cellular and Molecular Life Sciences 63:1125-1140. doi: 10.1007/s00018-005-5571-8.

Curran-Everett D. 2000. Multiple comparisons: philosophies and illustrations. American Journal of Physiology. Regulatory, Integrative and Comparative Physiology 279:R1-R8.

Essenfelder GM, Bruzzone R, Lamartine J, Charollais A, Blanchet-Bardon C, Barbe MT, Meda P, Waksman G. 2004. Connexin30 mutations responsible for hidrotic ectodermal dysplasia cause abnormal hemichannel activity. Human Molecular Genetics 13:1703-1714. doi: 10.1093/hmg/ddh191.

Gerido DA, DeRosa AM, Richard G, White TW. 2007. Aberrant hemichannel properties of Cx26 mutations causing skin disease and deafness. American Journal of Physiology. Cell Physiology 293:C337-C345. doi: 10.1152/ ajpcell.00626.2006.

Haruna K, Suga Y, Oizumi A, Mizuno Y, Endo H, Shimizu T, Hasegawa T, Ikeda S. 2010. Severe form of keratitisichthyosis-deafness (KID) syndrome associated with septic complications. The Journal of Dermatology 37:680-682. doi: 10.1111/j.1346-8138.2010.00839.x. 
Huckstepp RT, Eason R, Sachdev A, Dale N. 2010a. $\mathrm{CO}_{2}$-dependent opening of connexin 26 and related beta connexins. The Journal of Physiology 588:3921-3931. doi: 10.1113/jphysiol.2010.192096.

Huckstepp RT, Id Bihi R, Eason R, Spyer KM, Dicke N, Willecke K, Marina N, Gourine AV, Dale N. 2010b. Connexin hemichannel-mediated $\mathrm{CO}_{2}$-dependent release of ATP in the medulla oblongata contributes to central respiratory chemosensitivity. The Journal of Physiology 588:3901-3920. doi: 10.1113/jphysiol.2010.192088.

Janecke AR, Hennies HC, Gunther B, Gansl G, Smolle J, Messmer EM, Utermann G, Rittinger O. 2005. GJB2 mutations in keratitis-ichthyosis-deafness syndrome including its fatal form. American Journal of Medical Genetics. Part A 133A:128-131. doi: 10.1002/ajmg.a.30515.

Jonard L, Feldmann D, Parsy C, Freitag S, Sinico M, Koval C, Grati M, Couderc R, Denoyelle F, Bodemer C, Marlin S, Hadj-Rabia S. 2008. A familial case of Keratitis-Ichthyosis-Deafness (KID) syndrome with the GJB2 mutation G45E. European Journal of Medical Genetics 51:35-43. doi: 10.1016/j.ejmg.2007.09.005.

Kelley PM, Cohn E, Kimberling WJ. 2000. Connexin 26: required for normal auditory function. Brain Research. Brain Research Reviews 32:184-188. doi: 10.1016/S0165-0173(99)00080-6.

Koppelhus U, Tranebjaerg L, Esberg G, Ramsing M, Lodahl M, Rendtorff ND, Olesen HV, Sommerlund M. 2010. A novel mutation in the connexin 26 gene (GJB2) in a child with clinical and histological features of keratitis-ichthyosis-deafness (KID) syndrome. Clinical and Experimental Dermatology 36:142-148. doi: 10.1111/j.1365-2230.2010.03936.x.

Meigh L, Greenhalgh SA, Rodgers TL, Cann MJ, Roper DI, Dale N. 2013. $\mathrm{CO}_{2}$ directly modulates connexin 26 by formation of carbamate bridges between subunits. eLife 2:e01213. doi: 10.7554/eLife.01213.

Mhaske PV, Levit NA, Li L, Wang HZ, Lee JR, Shuja Z, Brink PR, White TW. 2013. The human Cx26-D50A and Cx26-A88V mutations causing keratitis-ichthyosis-deafness syndrome display increased hemichannel activity. American Journal of Physiology. Cell Physiology 304:C1150-C1158. doi: 10.1152/ajpcell.00374.2012.

Sanchez HA, Mese G, Srinivas M, White TW, Verselis VK. 2010. Differentially altered $\mathrm{Ca}^{2+}$ regulation and $\mathrm{Ca}^{2+}$ permeability in Cx26 hemichannels formed by the A40V and G45E mutations that cause keratitis ichthyosis deafness syndrome. The Journal of General Physiology 136:47-62. doi: 10.1085/jgp.201010433.

Sbidian E, Feldmann D, Bengoa J, Fraitag S, Abadie V, de Prost Y, Bodemer C, Hadj-Rabia S. 2010. Germline mosaicism in keratitis-ichthyosis-deafness syndrome: pre-natal diagnosis in a familial lethal form. Clinical Genetics 77:587-592. doi: 10.1111/j.1399-0004.2009.01339.x.

Stout C, Goodenough DA, Paul DL. 2004. Connexins: functions without junctions. Current Opinion in Cell Biology 16:507-512. doi: 10.1016/j.ceb.2004.07.014.

Wang N, De Bock M, Decrock E, Bol M, Gadicherla A, Vinken M, Rogiers V, Bukauskas FF, Bultynck G, Leybaert L. 2013. Paracrine signaling through plasma membrane hemichannels. Biochimica et Biophysica Acta 1828:35-50. doi: 10.1016/j.bbamem.2012.07.002.

Wenker IC, Sobrinho CR, Takakura AC, Moreira TS, Mulkey DK. 2012. Regulation of ventral surface $\mathrm{CO}_{2} / \mathrm{H}^{+}$-sensitive neurons by purinergic signalling. The Journal of Physiology 590:2137-2150. doi: 10.1113/jphysiol.2012.229666.

Xu J, Nicholson BJ. 2013. The role of connexins in ear and skin physiology - functional insights from diseaseassociated mutations. Biochimica et Biophysica Acta 1828:167-178. doi: 10.1016/j.bbamem.2012.06.024. 